Abstracta Iranicacta Iranica

Revue bibliographique pour le domaine irano-aryen

Volume 32-33 | 2013

Comptes rendus des publications de 2009-2010

\title{
Nile Green. Islam and the Army in Colonial India. Sepoy religion in the service of empire
}

\section{Fabrizio Speziale}

\section{OpenEdition}

1 Journals

Édition électronique

URL : http://journals.openedition.org/abstractairanica/40630

DOI : 10.4000/abstractairanica.40630

ISSN : 1961-960X

\section{Éditeur :}

CNRS (UMR 7528 Mondes iraniens et indiens), Éditions de l'IFRI

\section{Édition imprimée}

Date de publication : 1 décembre 2013

ISSN : 0240-8910

\section{Référence électronique}

Fabrizio Speziale, "Nile Green. Islam and the Army in Colonial India. Sepoy religion in the service of empire ", Abstracta Iranica [En ligne], Volume 32-33 | 2013, document 275, mis en ligne le 01 juillet 2016, consulté le 03 octobre 2020. URL : http://journals.openedition.org/abstractairanica/40630; DOI : https://doi.org/10.4000/abstractairanica.40630

Ce document a été généré automatiquement le 3 octobre 2020.

Tous droits réservés 
Nile Green. Islam and the Army in Colonial India. Sepoy religion in the service of empire

Fabrizio Speziale 


\section{RÉFÉRENCE}

Nile Green. Islam and the Army in Colonial India. Sepoy religion in the service of empire.

Cambridge, Cambridge University Press, 2009, 217 p. + xiii. (Cambridge Studies in Indian History and Society)

Dans cet ouvrage, très original, Nile Green examine les aspects multiples du rapport entre la religion des sepoy musulmans et l'armée coloniale britannique. L'A. explore les croyances religieuses des sepoy musulmans et notamment leur dévotion vers les faqï et les soufis. L'ouvrage examine le sujet à travers l'analyse détaillée d'un cas particulier, celui du contingent britannique de l'état Hyderabad, qui à l'époque coloniale, sous les Nizāāms, devient le plus grand état princier musulman du sous-continent. La période étudiée est celle entre environ 1850 et 1930. L'A. présente notamment les figures de trois faqiir qui comptèrent des fidèles parmi les sepoy du contingent de Hyderabad: Afụal Šāh Biyābānī (m.1273/1856), Banē Miyān (d.1339/1921) and Tāj al-Dīn Bābā (d.1344/1925). Les sources principales sur la vie d'Afżal Šāh et de Banē Miyān sont respectivement l'Afạal al-karāmāt et l'A'zam al-karāmāt, des ouvrages biographiques en ourdou qui furent composé par deux membres de leurs familles au cours des premiers décades du 1900. La famille d'Af̣̣al Šāh Biyābānī descendait d'Aḥmad al-Rifā‘ī (m. 1181), le maître soufi éponyme de l'ordre rifā‘̄ì, cependant, Afḍal šāh fut associé en particulier à la Qādiriya et à la Čištiya. Banē Miyān (d. 1339/1921) et Tāj al-Dīn Bābā étaient euxmêmes des soldats du contingent britannique et à cause de leurs conduites extatiques ils furent détenus dans les asiles d'aliénés coloniaux.

\section{AUTEURS}

\section{FABRIZIO SPEZIALE}

Université Sorbonne Nouvelle-Paris 3/Mondes iranien et indien, Paris 